\title{
Seleksi resin dan rubber processing oil (RPO) dalam pembuatan cushion gum sebagai perekat ban vulkanisir
}

\section{Resin and rubber processing oil (RPO) selection in the production of cushion gum as adhesive on retread tire}

\author{
Santi Puspitasari ${ }^{1 *}$, Norma Arisanti Kinasih ${ }^{1}$, Adi Cifriadi ${ }^{1}$, Arief Ramadhan ${ }^{1}$, Zahra Krishna \\ Hadi $^{2}$, Novita Putri Wahyuni², Mochamad Chalid ${ }^{3}$ \\ ${ }^{1}$ Balai Penelitian Teknologi Karet - Pusat Penelitian Karet, Jalan Salak No. 1 Bogor 16128, Indonesia \\ ${ }^{2}$ Politeknik STMI, Jalan Letjend Suprapto No. 26 Jakarta 10510, Indonesia \\ ${ }^{3}$ Fakultas Teknik Universitas Indonesia, Kampus UI Depok, Depok 16424, Indonesia \\ * Penulis korespondensi. Tel.: +62 2518319817 ; Faks.: +62 2518324047 \\ E-mail: puspitasari.santi@puslitkaret.co.id
}

Diterima: 8 April 2020

Direvisi: 12 Mei 2020

Disetujui: 12 Mei 2020

\begin{abstract}
Cushion gum is one of the most important materials in retread tire industry. Cushion gum is functioned as adhesive to bond worn old tire casing with new tread. The quality of cushion gum is strongly depended on the composition, within base polymer, tackifier-resin, and Rubber Processing Oil (RPO) plasticizer. The research on the quality of cushion gum compound was explored at various types of tackifier resin and RPO plasticizer. The experiment applied three types of tackifier resin (R1-R3), such as coumarone resin, resorcinol, and petro-derived hydrocarbon resin at $5 \mathrm{phr}$, and three types of RPO plasticizer (P1-P3) consisted of paraffinic oil, pine tar oil, and aromatic oil at 20 phr. Various dosage of RPO were only applied for pine tar oil as 12 and 20 phr. Cushion gum compound was milled by using two rolled laboratory open mill. Cushion gum compound was cured in hydraulic press machine at $150^{\circ} \mathrm{C}$ under $100 \mathrm{~kg} / \mathrm{cm}^{2}$ pressure. Afterward, mechanical and adhesion properties were assessed to evaluate appropriate type of tackifier resin and RPO plasticizer. The result revealed that the addition of various types of tackifier resin and RPO plasticizer affected curing characteristic which linearly followed with the mechanical and adhesion properties. Combination of $5 \mathrm{phr}$ coumarone resin and $20 \mathrm{phr}$ pine tar oil resulted in the most optimum cushion gum compound formula for retread tire.
\end{abstract}

Keywords: cushion gum, retread tire, rubber processing oil plasticizer, tackifier resin.

\begin{abstract}
ABSTRAK
Cushion gum merupakan salah satu material penting dalam industri ban vulkanisir. Cushion gum berfungsi sebagai perekat yang digunakan pada ban vulkanisir untuk melekatkan bagian karet casing ban lama dengan karet telapak yang baru. Kualitas cushion gum tergantung pada komposisi bahan penyusunnya yang utamanya terdiri dari polimer, resin tackifier, dan plasticizer Rubber Processing Oil (RPO). Riset ini dimaksudkan untuk mempelajari kualitas cushion gum yang dibuat dengan memformulasikan berbagai jenis dan dosis resin tackifier serta plasticizer RPO. Resin (R1-R3) yang digunakan terdiri dari resin coumarone, resorsinol, dan resin turunan hidrokarbon pada dosis 5 phr. Sementara jenis plasticizer RPO (P1-P3) yang dipelajari dalam riset meliputi minyak parafin, minyak pine tar, dan minyak aromatik pada dosis 20 phr. Variasi dosis RPO hanya dibatasi untuk jenis minyak pine tar, yaitu pada 12 dan 20 phr. Pembuatan kompon dilakukan dalam mesin giling terbuka skala laboratorium. Selanjutnya kompon cushion gum dicetak dalam mesin cetak hidrolik pada suhu $150{ }^{\circ} \mathrm{C}$ dan tekanan $100 \mathrm{~kg} / \mathrm{cm}^{2}$. Vulkanisat cushion gum kemudian diuji sifat mekanis dan kekuatan rekat. Hasil pengujian dievaluasi dan digunakan sebagai dasar dalam menentukan jenis dan dosis resin tackifier dan plasticizer RPO yang terbaik dalam pembuatan cushion gum. Hasil eksperimen menunjukkan bahwa variasi jenis dan dosis resin tackifier dan plasticizer RPO berpengaruh terhadap karakteristik pematangan kompon, sifat mekanis dan kekuatan rekat vulkanisat cushion gum. Formula
\end{abstract}


karet cushion gum paling optimum diperoleh dari perpaduan resin tackifier jenis coumarone sebesar 5 phr dan plasticizer RPO jenis minyak pine tar sebesar 20 phr.

Kata kunci: ban vulkanisir, cushion gum, resin tackifier, rubber processing oil plasticizer.

\section{PENDAHULUAN}

Industri ban vulkanisir menjadi industri hilir karet terbesar kedua di Indonesia. Selain karena digerakkan oleh lebih dari 1200 unit industri yang mayoritas berskala UMKM dengan total produksi ban vulkanisir mencapai 20,48 juta unit pada tahun 2017, industri ban vulkanisir mampu menyerap rata-rata sebesar $25 \%$ dari total konsumsi domestik karet alam selama periode 2011-2017 (Dewan Karet Indonesia, 2018). Pemerintah berencana memberlakukan SNI wajib sebagai acuan standar mutu untuk produk ban vulkanisir yang harus dipenuhi oleh industri ban vulkanisir. Standar mutu diharapkan dapat berkontribusi dalam memberikan jaminan keamanan bagi pengguna ban vulkanisir.

Segmen pasar ban vulkanisir didominasi oleh industri penyedia jasa angkutan orang maupun barang. Industri ini memerlukan biaya operasional yang cukup tinggi untuk pengadaan ban pengganti (replacement tire). Oleh karena itu untuk menghemat biaya operasional, industri penyedia jasa angkutan lebih memilih menggunakan ban vulkanisir dibanding dengan yang baru. Teknologi vulkanisir ban dianggap sebagai proses yang dapat memperpanjang umur pakai ban secara ekonomis sekaligus ramah lingkungan karena dapat meminimalisir efek buruk limbah ban bekas terhadap kelestarian lingkungan (Simic \& Dabic-Ostojic, 2017; Miandad et al., 2018; Dong et al., 2019). Harga penjualan ban vulkanisir hanya sekitar 30-50\% lebih murah dari ban baru, namun mampu memberikan keunggulan dalam memperpanjang umur pakai ban hingga $75-100 \%$ (Uriarte-Miranda et al., 2018).

Proses vulkanisir ban dilakukan dengan saling melekatkan komponen komposit karet yang terdiri atas casing ban lama, cushion gum, dan telapak ban yang baru (kompon maupun vulkanisat) (Subulan et al., 2015). Cushion gum adalah lembaran tipis kompon karet yang lunak dan lengket untuk digunakan dalam proses vulkanisir ban untuk merekatkan karet dengan karet atau karet dengan lapisan benang (ply) (Gent \& Walter, 2005). Kekuatan rekat cushion gum sangat menentukan kualitas produk ban vulkanisir, terutama yang diproses secara vulkanisir dingin (cold cure) (Bakhshandeh \& Soltanalinegad, 2000). Cushion gum yang termasuk dalam kategori pressure-sensitive adhesive, apabila berkualitas rendah maka dapat mengakibatkan telapak ban vulkanisir terlepas dari bagian sidewall pada saat digunakan. Kerusakan pada ban vulkanisir dapat membahayakan keselamatan pengguna ban vulkanisir.

Cushion gum tersusun dari karet sebagai base elastomer dan bahan kimia karet. Pemilihan jenis bahan dan penentuan dosis bahan penyusun kompon sangat menentukan karakteristik cushion gum, baik sifat fisis maupun mekanis, termasuk kekuatan rekat. Karet alam banyak digunakan sebagai bahan baku cushion gum di industri vulkanisir. Sementara bahan kimia karet yang berperan penting dalam menentukan kualitas cushion gum adalah resin tackifier dan plasticizer rubber processing oil (Basak et al., 2012; Han et al., 2018). Campuran karet dengan tackifier dan plasticizer dapat menghasilkan kompon yang memiliki storage modulus rendah dan kekuatan rekat yang baik (Deng, 2016).

Plasticizer Rubber Processing Oil (RPO) yang ditambahkan dalam kompon karet berfungsi untuk menurunkan viskositas dan meningkatkan dispersi bahan pengisi dalam kompon karet (Siwarote et al., 2017). Jenis plasticizer RPO yang banyak digunakan pada industri ban adalah plasticizer RPO berbasis petroleum, seperti minyak parafinik, minyak naftanik, dan minyak aromatik yang banyak mengandung bahan karsinogenik (Xu et al., 2020). Penurunan kuantitas produksi petroleum semakin memaksa industri bahan kimia karet mencari plasticizer RPO berbasis bahan alam sebagai alternatif pengganti petro-based RPO (Bocque et al., 2016). Minyak pine tar berpotensi digunakan sebagai bio-based RPO dalam produksi cushion gum. Selain memiliki sifat pelunakan, minyak pine tar juga bersifat lengket (tacky). Minyak pine tar mengandung terpentin, resin, guaiacol, kreosol, metil kreosol, fenol, florol, toluen, silena, dan berbagai hidrokarbon lainnya (Barnes \& Greive, 2017). Adanya kandungan resin dalam minyak pine tar menyebabkan kompon karet memiliki 
kelengketan yang baik (Banerjee, 2019).

Resin tackifier ditambahkan dalam kompon karet berfungsi sebagai peningkat kekerasan dan kekuatan rekat. Berdasarkan penelitian terdahulu, yang telah dilakukan oleh Raethong dan Boonkerd (2017), dapat diketahui bahwa kinerja resin tackifier dalam meningkatkan kerekatan atau daya adhesi karet dipengaruhi oleh perpanjangan rantai (chain entanglement) dan tingkat polaritas antar molekul karet dan molekul tackifier. Efek daya adhesi tackifier semakin besar apabila memiliki rantai molekul yang lebih pendek dari karet dan tingkat polaritas yang mendekati karet.

Penelitian eksperimental pada skala laboratorium ini dimaksudkan untuk mempelajari pengaruh jenis dan dosis resin tackifier dan plasticizer RPO terhadap karakteristik fisis dan mekanis perekat cushion gum pada ban vulkanisir. Penelitian ini diharapkan mampu memberikan solusi pada ketersediaan cushion gum berkualitas unggul dan lebih ramah lingkungan untuk memenuhi kebutuhan pasar lokal sebagai substitusi produk impor yang serupa.

\section{BAHAN DAN METODE Bahan Penelitian}

Bahan yang digunakan dalam pembuatan kompon cushion gum terdiri dari karet alam tingkatan mutu Ribbed Smoked Sheet 1 (RSS 1), dengan nilai viskositas Mooney 96,5 ML 1+4 pada $100{ }^{\circ} \mathrm{C}$, diperoleh dari UD. Sukses Jaya Makmur, Bogor. Resin tackifier terdiri resin resorsinol dan resin turunan hidrokarbon (aromatik tak jenuh C9/C10) Ex. Lanxess serta resin coumarone yang seluruhnya diperoleh dari PT. Multi Citra Chemindo Nusa, Jakarta. Plasticizer RPO yang meliputi paraffinic oil, pine tar oil, dan aromatic oil diperoleh dari pemasok lokal. Bahan kimia karet lainnya, meliputi karbon hitam CB N330, sulfur, paraffin wax, asam stearat, $\mathrm{ZnO}, N$-cyclohexyl2-benzothiazole sulphenamide (CBS), N-(1,3dimethylbutyl)-N'-phenyl-p-phenylene diamine (6PPD), dan polymerized 1,2-dihydro-2,2,4trimethylquinoline (TMQ). Seluruh bahan kimia karet yang digunakan pada tingkatan mutu teknis dan diperoleh dari PT. Multi Citra Chemindo Nusa, Jakarta.

\section{Peralatan Penelitian}

Peralatan yang digunakan pada penelitian ini meliputi mesin giling terbuka skala laboratorium (two rolled laboratory scale open mill) merek
Berstorf untuk pembuatan kompon karet cushion gum. Moving Die Rheometer (MDR) merek Alpha 2000 dari Alpha Technologies untuk analisis karakteristik pematangan, mesin cetak hidrolik yang diproduksi oleh Hirara \& Co. Ltd. untuk mencetak kompon menjadi vulkanisat sampel uji cushion gum, Frank Durometer untuk pengujian kekerasan (Shore A), dan Universal Testing Machine (UTM) merek Lloyd 2000R untuk pengujian sifat tarik dan UTM Merek Instron untuk pengujian kekuatan rekat (adhesive strength).

\section{Metode Penelitian}

\section{Pembuatan kompon dan vulkanisat (sampel} uji) cushion gum

Formulasi kompon karet cushion gum tersusun atas elastomer dasar dan bahan kimia karet. Bahan kimia karet yang divariasikan dalam formulasi kompon cushion gum adalah resin tackifier (R) dan rubber processing oil plasticizer (RPO, P). Tabel 1 merangkum jenis dan dosis bahan yang digunakan dalam pembuatan kompon karet cushion gum dalam riset. Dari Tabel 1, dapat dilihat bahwa formulasi kompon karet cushion gum dibedakan menjadi dua, yaitu berdasarkan variasi jenis resin pada dosis 5 per hundred rubber (phr) dan variasi jenis RPO pada dosis $20 \mathrm{phr}$. Selanjutnya variasi dosis RPO hanya dilakukan untuk jenis minyak pine tar sebesar 12 dan $20 \mathrm{phr}$. Dalam riset ini fokus untuk mengetahui pengaruh minyak pine tar dalam pembuatan cushion gum pada berbagai jenis resin. Sementara, minyak parafin dan aromatik digunakan sebagai pembanding. Dosis minyak pine tar ditetapkan dengan mengacu pada penelitian sebelumnya yang telah dilakukan oleh Hetzel (2010). Penelitian tersebut menggunakan 5-60 phr plasticizing terpene resin dalam formulasi cushion gum. Kompon cushion gum harus bersifat lunak agar mudah diaplikasikan pada saat pemasangan telapak ban baru pada permukaan ban gundul sehingga memerlukan RPO pada dosis relatif besar. Sedangkan resin tackifier seringkali digunakan dalam formulasi kompon karet pada dosis sebesar 1-5 phr (White \& De, 2001).

Pembuatan kompon karet cushion gum dalam mesin giling terbuka mengikuti prosedur yang dituangkan dalam ASTM D 3182, dengan urutan penambahan bahan seperti disajikan pada Tabel 2. Kompon karet cushion gum yang telah dibuat selanjutnya disimpan pada suhu ruang selama 24 jam agar bahan kimia karet dapat semakin terdistribusi sempurna dalam matrik karet sebelum 
Tabel 1. Formula cushion gum dengan berbagai jenis resin dan RPO.

\begin{tabular}{|c|c|c|c|c|c|c|}
\hline \multirow{3}{*}{ Bahan } & \multicolumn{6}{|c|}{ Dosis (phr) } \\
\hline & \multicolumn{3}{|c|}{ Variasi Jenis Resin } & \multicolumn{3}{|c|}{ Variasi Jenis RPO } \\
\hline & R1 & $\mathrm{R} 2$ & R3 & P1 & P2 & P3 \\
\hline RSS & 100,0 & 100,0 & 100,0 & 100,0 & 100,0 & 100,0 \\
\hline $\mathrm{ZnO}$ & 5,0 & 5,0 & 5,0 & 5,0 & 5,0 & 5,0 \\
\hline Asam stearat & 2,0 & 2,0 & 2,0 & 2,0 & 2,0 & 2,0 \\
\hline TMQ & 2,0 & 2,0 & 2,0 & 2,0 & 2,0 & 2,0 \\
\hline 6 PPD & 2,0 & 2,0 & 2,0 & 2,0 & 2,0 & 2,0 \\
\hline Paraffin wax & 3,5 & 3,5 & 3,5 & 3,5 & 3,5 & 3,5 \\
\hline CB N330 & 50,0 & 50,0 & 50,0 & 50,0 & 50,0 & 50,0 \\
\hline CBS & 1,6 & 1,6 & 1,6 & 1,6 & 1,6 & 1,6 \\
\hline Sulfur & 2,2 & 2,2 & 2,2 & 2,2 & 2,2 & 2,2 \\
\hline Resin coumarone & 5,0 & - & - & 5,0 & 5,0 & 5,0 \\
\hline Resorcinol & - & 5,0 & - & - & - & - \\
\hline Resin turunan hidrokarbon & - & - & 5,0 & - & - & - \\
\hline Minyak pine tar & 12,0 & 12,0 & 12,0 & 20,0 & - & - \\
\hline Minyak parafin & - & - & - & - & 20,0 & - \\
\hline Minyak aromatik & - & - & - & - & - & 20,0 \\
\hline
\end{tabular}

Tabel 2. Tahapan penggilingan bahan kompon cushion gum.

\begin{tabular}{|c|c|c|}
\hline \multirow{2}{*}{$\begin{array}{l}\text { Waktu penggilingan } \\
\text { (menit) }\end{array}$} & \multicolumn{2}{|c|}{ Bahan yang dimasukkan } \\
\hline & Formula Resin & Formula RPO \\
\hline $0-5$ & RSS dan resin & RSS dan coumarone resin \\
\hline $6-8$ & $\mathrm{ZnO}$ dan asam stearat & $\mathrm{ZnO}$ dan asam stearat \\
\hline 9 & TMQ & TMQ \\
\hline $10-16$ & $\begin{array}{l}6 \text { PPD, Antilux, karbon hitam, } \\
\text { dan pine tar oil }\end{array}$ & $\begin{array}{l}6 \text { PPD, Antilux, karbon hitam, } \\
\text { dan RPO }\end{array}$ \\
\hline 17 & CBS & CBS \\
\hline 18 & Sulfur & Sulfur \\
\hline 28 & \multicolumn{2}{|c|}{ Pencampuran dan homogenisasi } \\
\hline
\end{tabular}

kompon diuji karakteristik pematangannya. Hasil dari pengujian karakteristik pematangan digunakan sebagai acuan dalam mencetak kompon menjadi vulkanisat sampel uji dalam mesin cetak hidrolik. Selama pencetakan kompon menjadi vulkanisat, mesin cetak hidrolik dioperasikan pada suhu 150 ${ }^{\circ} \mathrm{C}$ dan tekanan $100 \mathrm{~kg} / \mathrm{cm}^{2}$. Vulkanisat cushion gum, yang diperoleh, kemudian diuji sifat mekanis dan kekuatan rekat.

\section{Karakterisasi pematangan}

Sampel kompon yang diperoleh dari proses compounding dan telah diperam selama 24 jam, dicuplik sekitar $50 \mathrm{~g}$ untuk pengujian karakteristik pematangan (curing characteristic). Pengujian karakteristikpematangan dilakukan denganmetode sesuai ASTM D 2084-17 menggunakan instrumen MDR Alpha 2000 pada suhu $150{ }^{\circ} \mathrm{C}$ selama 30 menit. Data yang diperoleh dari hasil karakteristik vulkanisasi meliputi torsi maksimum $\left(\mathrm{S}_{\max }\right)$ dan minimum $\left(\mathrm{S}_{\min }\right)$, delta torsi $\left(\mathrm{S}_{\max }-\mathrm{S}_{\min }\right)$, waktu optimum vulkanisasi $\left(\mathrm{t}_{90}\right)$, waktu pra-vulkanisasi $\left(t_{s 2}\right)$ dan indeks kecepatan reaksi. Indeks kecepatan reaksi (CRI) dihitung berdasarkan formula yang dikembangkan oleh Mondal et al. (2019) sebagai berikut:

$C R I=\frac{100}{t_{90}-t_{s 2}}$

\section{Pengujian sifat mekanis dan kekuatan rekat cushion gum}

Vulkanisat sampel uji cushion gum dicetak menggunakan mesin press hidrolik pada suhu $150{ }^{\circ} \mathrm{C}$ dengan tekanan sebesar $100 \mathrm{~kg} / \mathrm{cm}^{2}$. Lama waktu pemasakan masing-masing kompon disesuaikan dengan waktu pemasakan optimum $\left(t_{90}\right)$ hasil pengujian karakteristik vulkanisasi. Vulkanisat kemudian diuji sifat mekanis yang meliputi kekerasan, kuat tarik, dan perpanjangan putus. Prosedur pengujian kekerasan vulkanisat (Shore A) mengacu pada ASTM D 2240-15. Selanjutnya, metode pengujian kuat tarik $\left(\mathrm{N} / \mathrm{mm}^{2}\right)$ dan perpanjangan putus (\%) mengacu pada ASTM D412-16. Sementara uji kekuatan rekat dilakukan 
berdasarkan prosedur yang diatur dalam ASTM D 413-98.

\section{HASIL DAN PEMBAHASAN Karakteristik Pematangan}

Seleksi komposisi bahan penyusun kompon karet cushion gum yang terdiri dari karet RSS 1, resin tackifier dan plasticizer RPO didasarkan pada karakteristik pemasakan, sifat mekanis, dan kekuatan rekat cushion gum. Hasil karakterisasi pematangan kompon secara lengkap disajikan pada Tabel 3. Dari Tabel 3 terlihat bahwa resin coumarone menghasilkan derajat ikatan silang terendah dibandingkan jenis resin resorsinol dan resin hidrokarbon pada dosis minyak pine tar yang sama. Selanjutnya minyak parafin juga menunjukkan nilai derajat ikatan silang paling rendah dibandingkan minyak pine tar dan minyak aromatik pada dosis resin coumarone yang ditetapkan konstan. Sementara pada perpaduan resin coumarone dan minyak pine tar terlihat bahwa peningkatan dosis minyak pine tar dari 12 phr (R1) menjadi 20 phr (P1) justru menaikkan derajat ikatan silang. Derajat ikatan silang dan kekakuan karet diindikasikan dari nilai delta torsi $\left(\mathrm{S}_{\max }-\mathrm{S}_{\min }\right)$ (Movahed et al., 2015).

Derajat ikatan silang bergantung pada kompatibilitas dan kelarutan resin dan RPO dalam karet.Paraffinic oilmemiliki kompatibilitas rendah terhadap karet alam RSS 1 sehingga memberikan nilai derajat ikatan silang yang rendah (Sasaki et al., 2005; Lee \& Gan, 2013). Hasil sebaliknya ditunjukkan pada aplikasi fenil resin dan aromatic oil. Hasil studi Flanigan et al. (2013) menunjukkan bahwa aromatic oil memiliki kompatibilitas yang baik dengan karet alam, maka kompon P3 memiliki nilai derajat ikatan yang relatif tinggi meskipun tidak sebaik penggunaan minyak pine tar. Minyak pine tar dapat dianggap sebagai biobased rubber plasticizer yang saat ini telah banyak dipakai dalam industri manufaktur ban kendaraan bermotor. Polaritas minyak pine tar mendekati karet alam sehingga memiliki kompatibilitas dan kelarutan yang baik. Sedangkan antara minyak parafin dan aromatik yang termasuk dalam golongan mineral oil memiliki komposisi yang berbeda yang mempengaruhi kompatibilitasnya terhadap karet alam (Oter et al., 2011). Minyak aromatik mengandung senyawa aromatis dalam jumlah besar (> 65\% wt) (Syamin et al., 2017). Senyawa aromatik menyebabkan minyak aromatik lebih bersifat polar daripada minyak parafin.
Minyak aromatik paling sesuai digunakan untuk karet alam dan karet SBR yang bersifat polar. Sedangkan minyak parafin paling sesuai untuk karet EPDM yang bersifat tidak polar (Rodgers, 2004).

Waktu vulkanisasi $\left(t_{90}\right.$ dan $\left.t_{\mathrm{s} 2}\right)$ dan indeks kecepatan reaksi (CRI) sangat dipengaruhi oleh ikatan silang yang terbentuk. Semakin banyak ikatan silang yang terbentuk maka akan mempercepat waktu vulkanisasi (semakin kecil nilai $t_{90}$ ) dan semakin besar CRI nya. Hubungan nilai antara $t_{90}$ dan CRI disajikan pada Gambar 1. Pada Gambar 1 tampak bahwa $t_{90}$ dan CRI memiliki hubungan yang terbalik yang berarti bahwa pada CRI yang tinggi akan diikuti dengan waktu vulkanisasi optimal yang singkat. Resin coumarone memberikan waktu vulkanisasi optimal terlama dengan nilai CRI terendah dibandingkan dengan jenis resin yang lain (formula R1), diperkirakan disebabkan oleh terjadinya adsorpsi molekul akselerator (CBS) pada molekul resin coumarone sehingga menganggu jalannya reaksi vulkanisasi (Thaijaroen, 2011). Sementara pada kombinasi resin coumarone $5 \mathrm{phr}$ dan minyak pine tar $20 \mathrm{phr}$ (formula P1) menghasilkan waktu vulkanisasi optimal yang relatif singkat (19,47 menit) dengan waktu pra-vulkanisasi yang relatif panjang $(6,02$ menit). Waktu vulkanisasi tersebut masih lebih lambat dibandingkan dengan pengaruh dari minyak aromatik namun jauh lebih cepat daripada yang dihasilkan oleh minyak parafin. Adanya kandungan resinous acid dalam minyak pine tar mungkin sedikit menghambat laju vulkanisasi karet (Franta, 1989). Kondisi ini memberikan keuntungan bahwa pada saat pembuatan ban vulkanisir maka waktu yang diperlukan untuk vulkanisasi menjadi singkat sehingga industri dapat menghemat energi selama proses vulkanisir.

\section{Sifat Mekanis dan Kekuatan Rekat Cushion Gum}

Pengaruh penambahan resin tackifier dan plasticizer RPO pada mutu kompon karet cushion gum (sifat mekanis dan kekuatan rekat) disajikan pada Gambar 2. Penambahan resin tackifier dan plasticizer RPO pada kompon cushion gum terbukti berpengaruh terhadap karakteristik cushion gum. Umumya, resin tackifier ditambahkan ke dalam karet untuk meningkatkan kekerasan kompon, sebaliknya plasticizer untuk melunakkan kompon. Efek pengerasan kompon terbesar dihasilkan 
Tabel 3. Karakteristik pematangan kompon cushion gum.

\begin{tabular}{|c|c|c|c|c|c|c|}
\hline \multirow{3}{*}{ Parameter } & \multicolumn{6}{|c|}{ Sifat } \\
\hline & $\mathrm{R} 1$ & R2 & R3 & P1 & P2 & P3 \\
\hline & Resin coumarone & Resorsinol & Resin hidrokarbon & Pine tar & Paraffinic oil & Aromatic oil \\
\hline $\mathrm{S}_{\text {max }}(\mathrm{kg} . \mathrm{cm})$ & 8,38 & 12,43 & 10,18 & 12,48 & 6,90 & 10,58 \\
\hline $\mathrm{S}_{\min }^{\max }(\mathrm{kg} . \mathrm{cm})$ & 1,23 & 1,71 & 0,51 & 0,94 & 0,88 & 0,59 \\
\hline $\mathrm{S}_{\max }-\mathrm{S}_{\min }(\mathrm{kg} \cdot \mathrm{cm})$ & 7,15 & 10,72 & 9,67 & 11,54 & 6,02 & 9,99 \\
\hline $\mathrm{t}_{90}(\mathrm{~min}, \mathrm{sec})$ & 28,19 & 21,58 & 21,39 & 19,47 & 28,08 & 18,38 \\
\hline $\mathrm{t}_{\mathrm{s} 2}(\mathrm{~min}, \mathrm{sec})$ & 14,1 & 3,52 & 8,35 & 6,02 & 12,57 & 7,39 \\
\hline
\end{tabular}

oleh resin jenis resorsinol (R2). Sementara efek pelunakan tertinggi tampak pada penambahan minyak parafin. Peningkatan dosis minyak pine tar dari $12 \mathrm{phr}$ menjadi $20 \mathrm{phr}$ hanya menurunkan 1 poin kekerasan karet cushion gum. Kekerasan yang ideal untuk karet cushion gum adalah 45-60
Shore A. Pada dosis penambahan resin yang sama, kompon P3 memiliki nilai kekerasan tertinggi. Kondisi saat ini, penggunaan petroleum-based RPO dalam industri karet mulai dibatasi, sehingga formula R2 dan P3 menjadi tidak ideal digunakan pada skala industri.

$\because \mathrm{t} 90=\mathrm{ts} 2=\mathrm{CRI}$

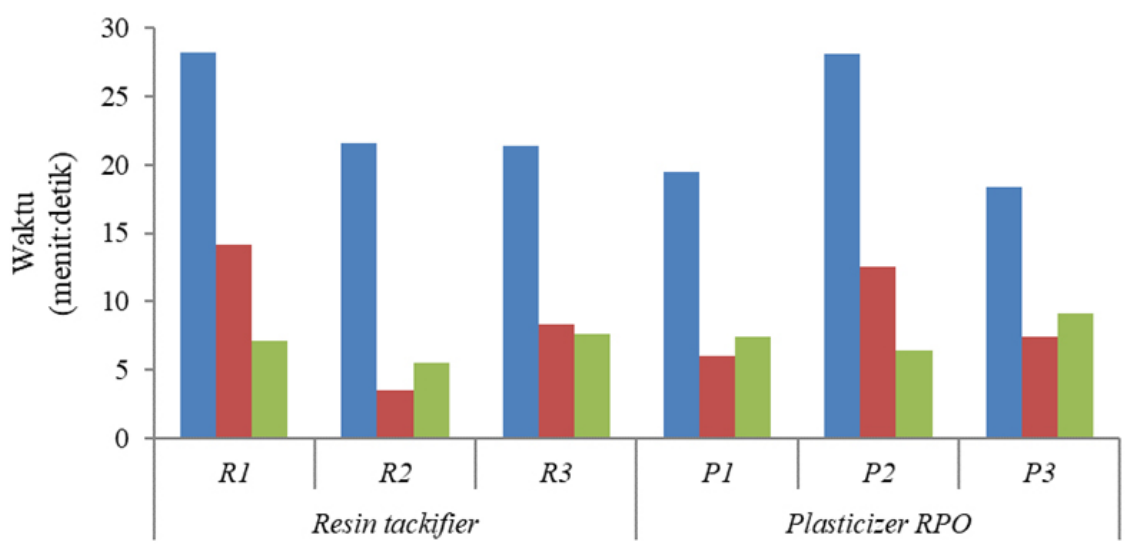

Gambar 1. Hubungan CRI dan $\mathrm{t}_{90}$ pada karakteristik pematangan kompon cushion gum.
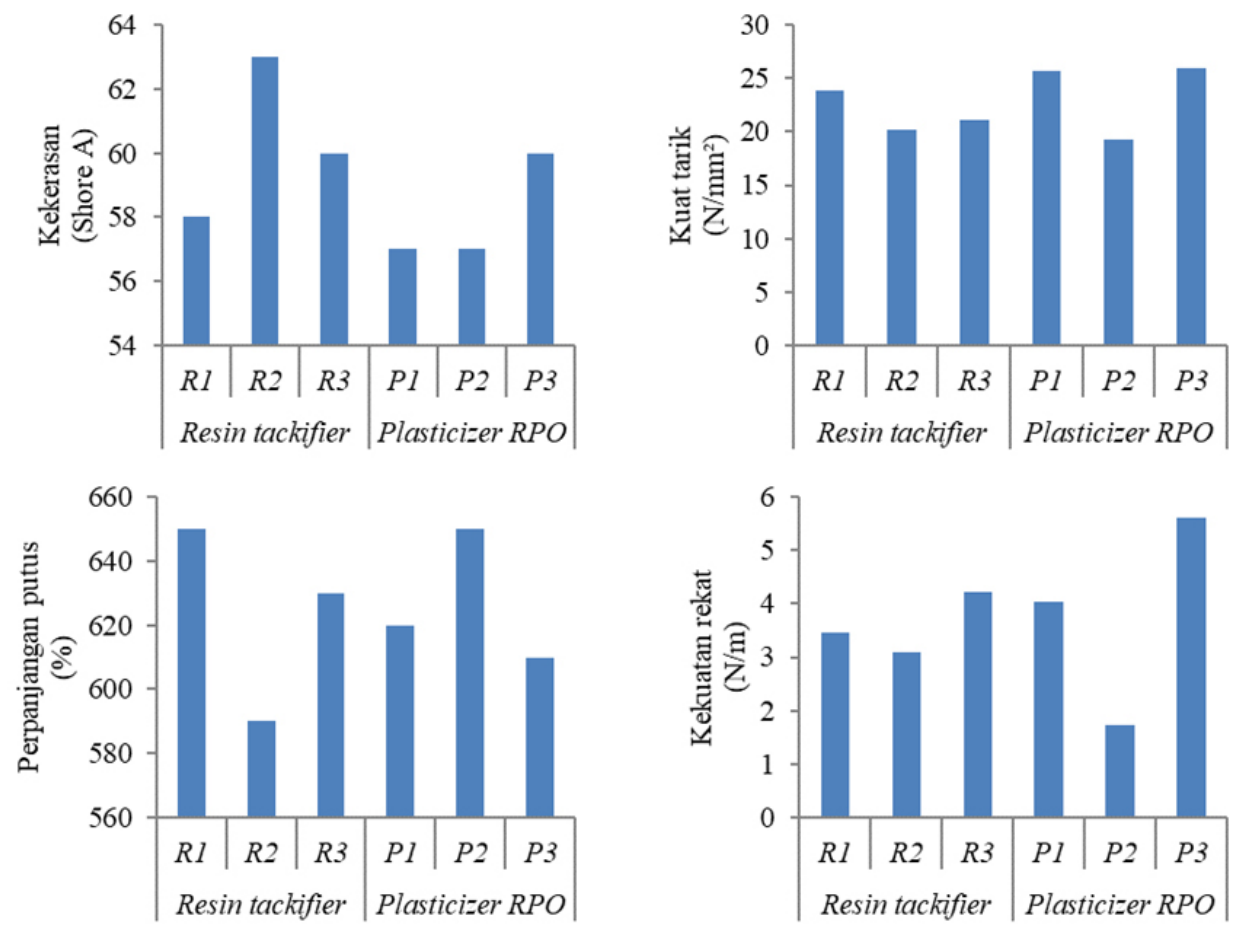

Gambar 2. Sifat mekanis dan kekuatan rekat vulkanisat cushion gum. 
Parameter sifat tarik atau elastisitas yang tampak pada nilai kuat tarik dan perpanjangan putus turut menentukan penilaian mutu karet cushion gum. Cushion gum yang baik, setidaknya, memiliki nilai kuat tarik minimal sebesar 18,63 $\mathrm{N} / \mathrm{mm}^{2}$ dan perpanjangan putus minimal sebesar 500\%. Dari Gambar 2 terlihat bahwa seluruh formula yang dirancang dalam eksperimen ini memiliki nilai kuat tarik di atas $18,63 \mathrm{~N} / \mathrm{mm}^{2}$ dan perpanjangan putus di atas $500 \%$. Penambahan dosis minyak pine tar dari $12 \mathrm{phr}$ menjadi 20 phr berakibat meningkatnya kuat tarik namun menurunkan perpanjangan putus, meskipunnya nilainya masih memenuhi nilai ideal cushion gum. Sifat kuat tarik yang tinggi pada formula P1 disebabkan karena tingginya nilai derajat ikatan silang pada kompon cushion gum tersebut.

Kekuatan rekat pada kompon cushion gum dipengaruhi oleh jumlah ikatan silang yang terbentuk pada kompon setelah penambahan resin dan RPO. Gambar 2 menunjukkan bahwa penambahan resin jenis hydrocarbon resin (R3) menghasilkan kekuatan rekat paling tinggi dibandingkan kedua jenis resin lainnya. Begitu pula penambahan RPO jenis aromatic oil (P3) menghasilkan kekuatan rekat terbesar dengan telapak ban vulkanisir. Namun demikian, nilai kuat tarik yang rendah pada formula R3 kurang sesuai digunakan untuk cushion gum pada skala besar. Dosis minyak pine tar dalam formulasi kompon cushion gum turut menaikkan kekuatan rekat cushion gum dari 3,45 menjadi 4,04.

\section{KESIMPULAN}

Cushion gum yang dibuat dalam penelitian ini tersusun dari polimer karet alam RSS 1, resin tackifierdanplasticizerRPO.Kinerjadariperpaduan ketiga bahan tersebut menentukan derajat ikatan silang yang terbentuk saat reaksi vulkanisasi cushion gum. Derajat ikatan silang berperan besar dalam karakteristik sifat cushion gum. Formula kompon karet cushion gum yang tersusun dari perpaduan antara $5 \mathrm{phr}$ resin coumarone dan 20 phr pine tar (kode P1) menghasilkan kualitas vulkanisat cushion gum terbaik yang ditunjukkan dengan nilai derajat ikatan silang tinggi (setara dengan nilai selisih torsi sebesar 11,54 kg.cm), waktu vulkanisasi optimal yang singkat $(19,47$ menit), kekerasan 57 Shore A, kuat tarik yang tinggi $\left(25,72 \mathrm{~N} / \mathrm{mm}^{2}\right)$, perpanjangan putus yang baik $(620 \%)$, dan kekuatan rekat sedang $(4,04)$. Sifat unggul formula P1 disebabkan karena adanya kompatibilitas dan kelarutan yang baik antara karet alam (RSS 1) dengan minyak pine tar. Dengan demikian dapat diketahui bahwa plasticizer RPO lebih berpengaruh terhadap mutu kompon cushion gum dibandingkan resin tackifier.

\section{UCAPAN TERIMA KASIH}

Ucapan terima kasih dan penghargaan tinggi disampaikan kepada Kementerian Ristek/ BRIN atas bantuan dana riset melalui program Insentif Sistem Inovasi Nasional Insinas T.A. 2020 (Kontrak Riset Nomor 24/INS-1/PPK/ E4/2020). Ucapan terima kasih disampaikan pula kepada para Tenaga Teknisi Penelitian dan Analis Laboratorium Pengujian Fisika serta Teknisi Pabrik Percobaan Balai Penelitian Teknologi Karet - Pusat Penelitian Karet atas konstribusi selama pelaksanaan kegiatan penelitian.

\section{DAFTAR PUSTAKA}

Banerjee, B. (2019). Tyre retreading. Calcutta, India: De Gruyter.

Barnes, T. M., \& Greive, K. A. (2017). Tropical pine tar: History, properties and use as a treatment for common skin condition. Australasian Journal of Dermatology, 58(2), 80-85. https://doi. org/10.1111/ajd.12427

Basak, G. C., Bandyopadhyay, A., \& Bhowmick, A. K. (2012). The role of tackifiers on the auto-adhesion behavior of EPDM rubber. Journal of Materials Science, 47, 3166-3176. https://doi.org/10.1007/ s10853-011-6151-y

Bakhshandeh, G. R., \& Soltanalinegad, M. A. (2000). Studies on the adhesion of cushion gum to carcass in retreaded tyre. Iranian Journal of Polymer Science and Technology, 13(4), 217-225. https:// doi.org/10.22063/jipst.2000.333

Bocque, M., Voirin, C., Lapinte, V., Caillol, S., \& Robin, J. (2016). Petro-based and bio-based plasticizers: Chemical structures to plasticizing properties. Journal of Polymer Science: Part A Polymer Chemistry, 54(1), 11-33. https://doi.org/10.1002/ pola.27917

Deng, X. (2016). Progress on rubber-based pressuresensitive adhesives. The Journal of Adhesion, 94(2), 77-96. https://doi.org/10.1080/00218464. 2016.1249573

Dewan Karet Indonesia. (2018). Statistik industri karet 2017. Jakarta, Indonesia: Dekarindo.

Dong, R., Zhao, M., \& Tang, N. (2019). Characterization of crumb tire rubber lightly pyrolyzed in waste cooking oil and the properties of its modified bitumen. Construction and Building Materials, 195, 10-18. https://doi.org/10.1016/j. conbuildmat.2018.11.044 
Flanigan, C., Beyer, L., Klekamp, D., Rohweder, D., \& Haakenson, D. (2013). Using bio-based plasticizers, alternative rubber. Rubber \& Plastic News, 15-19.

Franta, I. (1989). Elastomers and rubber compounding materials. Amsterdam, Netherlands: Elsevier Science Publisher.

Gent, A. N., \& Walter, J. D. (2005). The pneumatic tire. Washington DC, US: The National Highway Traffic Safety Administration, U.S. Department of Transportation.

Han, K., Li, M., Xu, H., \& Xiao, J. (2018). Study on hot vulcanized adhesive for rubber and metal bonding. AIP Conference Proceedings, 1995, 020008. https://doi.org/10.1063/1.5048739

Hetzel, P. D. (2010). US Patent No. US20100139825A1. Wahington, USA: U.S. Patent and Trademark Office.

Lee, S. Y., \& Gan, S. N. (2013). The adhesion properties of natural rubber pressure-sensitive adhesives using palm kernel oil-based alkyd resins as a tackifier. Composite Interfaces, 20(3), 177-188. https://doi.org/10.1080/15685543.2013.763515

Miandad, R., Barakat, M. A., Rehan, M., Aburiazaiza, A. S., Gardy, J., \& Nizami, A. S. (2018). Effect of advanced catalysts on tire waste pyrolysis oil. Process Safety and Environment Protection, 116, 542-552. https://doi.org/10.1016/j. psep.2018.03.024

Mondal, D., Ghorai, S., Rana, D., De, D., \& Chattopadhyay, D. (2019). The rubber-filler interaction and reinforcement in styrene butadiene rubber/devulcanized natural rubber composites with silica-graphene oxide. Polymer Composite, 40(S2), E1559-E1572. https://doi.org/10.1002/ pc. 25076

Movahed, S. O., Ansarifar, A., \& Mirzaie, F. (2015). Effect of various efficient vulcanization cure sytems on the compression set of a nitrile filled with different fillers. Journal of Applied Polymer Science, 132(8), 41512-41521. https://doi. org/10.1002/app.41512

Oter, M., Karaagac, B., \& Deniz, V. (2011). Substitution of aromatic processing oils in rubber compounds. KGK Rubber Point, 64, 48-51.

Raethong, P., \& Boonkerd, K. (2017). Effect of type and content of tackifier on adhesion of natural rubber and reclaimed natural rubber based sealant. IOP Conference Series: Materials Science and Engineering, 223, 012011. https:// doi.org/10.1088/1757-899X/223/1/012011

Rodgers, B. (2004). Rubber compounding chemistry and applications. New York, USA: Marcel Dekker Inc.

Sasaki, M., Nakamura, Y., Fujita, K., Kinugawa, Y., Iida, T., \& Urahama, Y. (2005). Relation between phase structure and peel adhesion of poly(styreneisoprene-styrene) triblock copolymer/tackifier blend system. Journal of Adhesion Science and Technology, 19(16), 1445-1457. https://doi. org/10.1163/156856105774805859

Simic, V., \& Dabic-Ostojic, S. (2017). Intervalparameter chance-constrained programming model for uncertainty-based decision making in tire retreading industry. Journal of Cleaner Production, 167, 1490-1498. https://doi. org/10.1016/j.jclepro.2016.10.122

Siwarote, B., Sae-Oui, P., Wirasate, S., \& Suchiva, K. (2017). Effects of bio-based oils on processing properties and cure characteristic of silica-filled natural rubber compounds. Journal of Rubber Research, 20(1), 1-19. https://doi.org/10.1007/ $\underline{\mathrm{BF} 03449138}$

Subulan, K., Tasan, A. S., \& Baykasoglu, A. (2015). Desingning an environmentally conscious tire closed-loop supply chain network with multiple recovery options using interactive fuzzy goal programming. Applied Mathematical Modelling, 39(9), 2661-2702. https://doi.org/10.1016/j. apm.2014.11.004

Syamin, Y. M., Azemi, S., \& Dzaraini, K. (2017). Evaluation of cooking oil as processing additive for natural rubber. ASEAN Journal on Science \& Technology for Development, 34(1), 17-25. https://doi.org/10.29037/ajstd.71

Thaijaroen, W. (2011). Effect of tackifiers on mechanical and dynamic properties of carbon-black-filled NR vulcanizates. Polymer Engineering and Science, 51(12), 2465-2472. https://doi.org/10.1002/ pen.22033

Uriarte-Miranda, M., Caballero-Morales, S., MartinezFlores, J., Cano-Olivos, P., \& Akulova, A. (2018). Reverse logistic strategy for the management of tire waste in Mexico dan Russia: Review and conceptual model. Sustainability, 10(10), 3398. https://doi.org/10.3390/su10103398

White, J. R., \& De, S. K. (2001). Rubber technologist handbook. Shropshire, UK: Rapra Technology Ltd.

Xu, H., Fan, T., Ye, N., Wu, W., Huang, D., Wang, D., Wang, Z., \& Zhang, L. (2020). Plasticization effect of bio-based plasticizers from soybean oil for tire tread rubber. Polymers, 12(3), 623. https:// doi.org/10.3390/polym 12030623 